\title{
FRA SAMFUNNSTJENESTE TIL SAMFUNNSSTRAFF Utviklingen i bruken av samfunnsstraffer og konfliktråd $i$ Norge.
}

\author{
AV SEKSJONSSJEF, DR. POLIT. PAUl LARSSON OG \\ UNIVERSITETSSTIPENDIAT JANE DULLUM
}

This article examines developments in the use of community sanctions in Norway. The list of such sanctions is limited, the most common being community service (introduced in 1984). Victim-offender mediation (introduced in 1981) is often presented as an "alternative sanction" in Norway, even though it is a type of restorative justice. Norwegian interest in alternatives to imprisonment blossomed during the late 1970 's and early 1980 's. The use of community service orders grew rapidly between 1984 and 1994, peaking at 1,026 sentences per year, but has since declined by nearly 50\% to 557 sentences. Progress in the use of victim-offender mediation has been more uneven, but its use has grown steadily since the early 1990's. There were 6,644 mediated cases in 1999. Efforts to introduce additional alternatives, such as intensive supervision programs (ISP) and electronic monitoring, have increased over the past ten years. The latest development is the introduction of "community punishment", a new sanction combining different types of community sanctions. Community punishment will be imposed by the court, but the specific content of the sanction will be decided by the Probation Service and may include ISP, electronic monitoring, community service orders, or other programs. *

Betegnelsen samfunnsstraff er ny i Norge. Begrepet kom i alminnelig bruk med Stortingsmeldingen "Om kriminalomsorgen" (1998) og er en samlebetegnelse for samfunnstjeneste, betinget fengsel med vilkår om tilsyn, betinget fengselsstraff hvor den dømte er på et tilsynsprogram og betinget fengselsstraff med vilkår om å delta i promilleprogram (Ot. prp. nr. 52000 - 2001). Det er, som man kan se, derved ikke noe bredt spekter av samfunnsstraffer. Vi har de "gode gamle" betingede straffene med tilsyn ( $\operatorname{strl} \S 53 \mathrm{nr}$. 2) som vi har hatt siden 1919 (Røstad 1993). Den eldste er likevel prøveløslatelse med tilsyn fra 1900. Hvor godt tilsynet fungerer og om en kan kalle det en selvstendig reaksjon kan diskuteres (Andenæs 1997).

Noen vil kanskje betegne $\S 12$ soning som en form for samfunnssoning ${ }^{1}$. Men dette er en spesiell ordning for dømte med ulike problemer - hovedsakelig med psykiske og rusrelaterte og vil ikke fungere som et "alternativ" for de fleste

\footnotetext{
* Title in English: From Community Service to Community Punishment. Developments in the Use of Community Sanctions and Victim-Offender Mediation in Norway. Orginal in Norwegian.
} 
dømte selv om dette er foreslått i Stortingsmelding nr. 271997 - 98 som en del av utslusingen fra fengsel.

Den mest fremtredende "nye" samfunnsstraffen er samfunnstjeneste hvor det i 1999 ble oversendt 546 saker til Kriminalomsorg i frihet (heretter KIF). Det har vært en markant nedgang de siste årene. I 1996 ble det igangsatt en fors $\emptyset \mathrm{ks}-$ ordning med program for promilledømte (strl. $§ 53 \mathrm{nr}$. 3e og nr. 6) hvor siste del av straffen avtjenes i tilknytning til et opplæringsprosjekt som setter søkelyset på skadene ved denne type atferd. Norge er derved et land med et lite antall samfunnssanksjoner og det kan se ut som vi ikke helt har fulgt utviklingen $\mathrm{i}$ andre vestlige land.

I Stortingsmelding nr. 271997 - 98 ble det lansert to "nye" samfunnsstraffer. Det er tilsynsprogram og tilsyn med elektronisk kontroll (hjemmesoning). Stortinget åpnet for en forsøksordning med tilsyn med elektronisk kontroll (Innst. S. Nr. 6. 1998 -99). Hva som faller inn under betegnelsen tilsynsprogram er mer uklart. Det kan være inspirert av hva som kalles Intensive Supervision Programs (ISP) innen internasjonal litteratur (Tonry og Hamilton 1995). Flere av de nye samfunnsstraffene, som tilsyn med elektronisk kontroll / hjemmesoning, er kombinasjoner av flere opplegg. Det er ofte intensivt tilsyn og kontroll kombinert med den elektroniske overvåkningen. Det kan også ilegges ulike påvirkningsprogrammer.

Konfliktrådets stilling er i denne forbindelse særegen. Det er ingen straff eller sanksjon, men skal i stedet fange opp saker før de kommer i retten. Det er ikke en alternativ sanksjon, men er ment å være et alternativ til domstolsbehandling. I praksis viser det seg at mange av sakene likevel ikke ville blitt påtalt. Konfliktrådsbehandling av saker bygger på frivillighet fra både offer og gjerningsmann. Det er likevel logisk å behandle konfliktrådet sammen med ulike samfunnssanksjoner fordi de er en del av samme bevegelse i retning av å skape alternativer i strafferettsapparatet.

\section{Kort om elektronisk kontroll, promille- og tilsynsprogram}

Hovedhensikten med å innføre nye samfunnsstraffer i dag er ifølge stortingsmeldingen:

"For å gi domstolene flere reaksjoner å velge mellom og samtidig redusere behovet for fengselsplasser, mener departementet at det bør overveies å innføre nye straffesanksjoner." (St. meld. 271997 - 98, s. 53)

Tidligere, når samfunnstjenesten ble innført, var hovedbegrunnelsen å skape nye alternativer til fengsel som ikke hadde de samme skadevirkningene. Ofte har man etterlyst sanksjoner som kan fylle hullet mellom betinget og ubetinget fengsel. Nye alternativer vil gi muligheter for domstolen til å nyansere straffeutmålingen. Målsetningen om å redusere behovet for fengselsplasser er noe mer 
problematisk. Ofte viser det seg at man ved å innføre nye sanksjoner ikke reduserer bruken av fengsel, men at man får en økning i bruken av både nye sanksjoner og fengsel. Sanksjonene oppfattes ikke lenger som alternativer som skal erstatte bruk av fengsel, men i stedet som en utvidelse av sanksjonsmulighetene. I USA hvor man er spesielt glad i å benytte fengsel er man ikke mindre glad i samfunnsstraffer. I 1997 var det hele 4.2 millioner dømte til Community Corrections, noe som utgjorde hele $72 \%$ av alle som ble dømt for kriminelle handlinger (Petersilia, $1998 \mathrm{~s}$. xi).

Det har siden 1996 vært drevet et prøveprosjekt med promilleprogram rettet mot dømte for rattfylleri - "fyllekjøring" (Kristoffersen 1999). Dette kan idømmes som en betingelse for de som ellers ville blitt dømt til ubetinget fengselsstraff for kjøring med promille. Vanligvis de med over 1.5 i promille eller promilleresidivister. Friomsorgen utfører vanligvis en personundersøkelse for å finne ut hvorvidt den tiltalte er egnet i denne forbindelse. Deler av straffen gjøres om til at man må følge et kurs under ledelse av friomsorgen. Dette kurset består i undervisning i 20 til 30 timer som strekker seg over to til tre måneder. Målsetningen er at den enkelte dømte skal få " $\varnothing \mathrm{kt}$ bevissthet om egen atferd og konsekvensene av denne." (ibid, s. 8) Man søker å synliggjøre følgene av fyllekjøring og alkoholmisbruk for at den enkelte skal ta ansvar for egne handlinger. Frem til april 1999 hadde 250 personer gjennomgått og avsluttet kurset.

Det er ennå ikke igangsatt noe prøveprosjekt med elektronisk hjemmesoning. Dette vil tidligst bli igangsatt i løpet av 2001. Det er særlig de svenske erfaringene med elektronisk hjemmesoning man er inspirert av i Norge (Larsson 1998). Målsetning ved den svenske ordningen er å redusere bruken av fengsel i saker hvor man ville ha idømt straff i opp til 3 måneder. Dette er ment som et reelt alternativ til fengsel. Denne målsetningen søker man å nå ved at personer dømte til fengsel kan få omgjort straffen til elektronisk tilsyn. Kontrollen av de dømte i det svenske opplegget var strengt, man hadde utstrakt bruk av hjemmebesøk og urinprøver ( 2 - 3 ganger i uka). Vilkårene som stilles er strenge. Man skal ikke ruse seg, må være tilstede på ulike steder til angitte tider. Det er liten toleranse for avvik. Fengsel er reaksjonen ved brudd på vilkår og de dømte opplevde straffen som streng og krevende (Andersson 1997). I forsøksperioden brøt 35 av 575 personer - det vil si ca. $6 \%$ ( 14 for alkohol, 8 for narko).

Svenske beskriver sine erfaringer med ordningen som gode og bygger dette især på brudd tallene. Men hva kan brudd tallene sammenlignes med, er de virkelig spesielt gode? Kanskje er brudd på frigang eller regellbrudd i fengsel hva en bør sammenligne med ved så tette kontrollopplegg.

Hva det siktes til med betegnelsen tilsynsprogram er med unntak av promilleprogrammet relativt diffust. Det hevdes ofte at man har drevet arbeid med tilsynsprogrammer på regionalt nivå i KIF. Det kan likevel i liten grad dokumenteres at det er utviklet faste programmer med unntak av promilleprogrammene. Tilsynsprogram beskrives på denne måten i Ot. prp. nr 5 (2000 - 2001): 
"En del tilsynsopplegg tilsvarer i dag inneholdet i et "program". Det vil blant annet si at de er strukturerte i form av at de har en begynnelse og en slutt, er rettet mot en bestemt gruppe og bygger på en vitenskapelig teori.” (s. 129)

Bruken av tilsyn har $\varnothing \mathrm{kt}$ de senere år fra 674 dommer i 1994 til 1033 i 1999. I disse tallene er det inkludert de som er dømt til promilleprogram (176 av de betingede dommer med tilsyn i 1999). Det er nå foreslått å opprette en egen reaksjon med navn samfunnsstraff hvor samfunnstjeneste, tilsyn og ulike programmer under ledelse av kriminalomsorgen skal inngå (Ot. prp. nr 52000 2001). Grensene mellom de ulike sanksjonene vil viskes ut, det vil bli brukt tilsynsprogram ved samfunnstjeneste og elektronisk soning.

\section{Samfunnstjeneste}

I "gamle dager" fantes det et knippe klart uttalte målsetninger for å innføre alternative reaksjoner. Den viktigste, som blant annet uttrykkes i St. meld. 104 1977 - 78, var å redusere bruken av fengsel. Fengselsstraffen hadde så mange veldokumenterte utilsiktede negative effekter på den dømte at man ønsket å benytte den i minst mulig grad. Mye energi ble lagt ned i arbeidet med å utvikle reelle alternativer til fengsel, som samfunnstjeneste. En annen uttalt målsetning var å gjøre den dømte bedre egnet til å leve et lovlydig liv. Om en ny reaksjon "fungerte" eller ei kunne derved måles ved å studere om den erstattet bruken av fengsel og ved å måle tilbakefall. Kunne man på toppen av dette spore en allmennpreventiv effekt så var det fint.

Den uttalte målsetningen for å idømme samfunnstjeneste er relativt nøkternt: "Målet med samfunnstjeneste er oppnådd ved at domfelte gjennomfører tjenesten uten å begå nye lovbrudd i samfunnstjenesteperioden." (Rundskriv 27.08. 1991 s. 5)

I den omstridte kriminalmeldingen (St. meld. 104. 1977 - 78) ble samfunnstjeneste foreslått sammen med weekend- og nattfengsel som alternativ til ordinær fengselsstraff. Meldingen viste til de skadene som fengsel påfører den enkelte dømte og søkte etter andre reaksjoner som kunne redusere de uheldige effektene ved soning. Innstilling S. Nr. $175(1979$ - 80) gav man uttrykk for at samfunnstjeneste tilpasset våre forhold ble sett på som "ein interessant straffereaksjon for einskilde lovbrytarar." (Instilling S. Nr. 175 (1979 - 80 s. 42) Det ble foreslått å igangsette fors $\emptyset \mathrm{k}$ med samfunnstjeneste for "å få meir kunnskap og røynsle" (s. 43), for bedre å kunne ta et mer endelig standpunkt til reaksjonsformen. Det ble utarbeidet en utredning om samfunnstjeneste "Prøveprosjekt med samfunnstjeneste" (NOU 1982: 4) hvor det ble foreslått å igangsette et prøveprosjekt i Rogaland, det ble samtidig gitt visse retningslinjer for denne aktiviteten (Larsson 1994).

Prøveprosjektet i Rogaland kom i gang 1984, og i 1985 ble det utvidet til Hordaland og Hedmark/Oppland. Ordningen ble innført i stadig flere fylker, og 
i 1989 ble det erklært landsomfattende. Samfunnstjenesten ble en alminnelig straff i 1991 ved at den fikk sin egen lov (Straffelovens § 28 a,b,c).

Den praktiske gjennomføringen av tjenesten ligger inn under kriminalomsorgen. En av kriminalomsorgens oppgaver er å utføre personundersøkelser av tiltalte man anser vil kunne dømmes til samfunnstjeneste. Ved personundersøkelsen søker man informasjon om den enkelte som kan belyse hvor godt han er egnet til å gjennomføre en samfunnstjenestedom. Man ser blant annet på rus bruk, psykisk helse og den sosiale livssituasjon den enkelte er i. De skal også skaffe oppdragsgivere og føre tilsyn med at den dømte overholder soningsvilkårene. Tilsynet skjer vanligvis ved at KIF møter hos oppdragsgiver når den dømte er i arbeid eller ved at de kontakter oppdragsgiver for å forhøre seg.

Samfunnstjeneste ble frem til 1991 gitt som vilkår ved betinget dom etter $\S$ 53.3 i straffeloven. Den dømte måtte samtykke i samfunnstjeneste ellers ble det oppfattet at dommen kunne stride mot Konvensjonen om beskyttelse av menneskerettighetene og de grunnleggende friheter (Art. 4 om tvangsarbeid). Ved brudd på vilkår kan dommen omgjøres til fengselsstraff. Man vurderer bruddets karakter og hvorvidt den domfelte tidligere har brutt vilkår, avgjørende er det dessuten om det er brudd på sær- eller grunnvilkår (det vil si ny kriminalitet). Ved bagatellmessige forhold er det ikke meningen at straffen skal omgjøres. Frem til midten av 90- tallet lå brudd prosenten på ca. 30. De senere år har det skjedd en reduksjon slik at tallene ligger rundt 25\%, i 1999 var det $27 \%$ (Kriminalomsorgens årbok 1999). En relativt stor andel av dette er brudd på særvilkår, det vil si vilkår i forbindelse med gjennomføringen av soningen som beruselse, ugrunnet fravær eller sviktende arbeidsinnsats (Larsson 1994). Det kan være ulike grunner til nedgangen i brudd. At man har blitt mer selektive i hvem man finner egnet, at kontrollen har blitt mindre intensiv eller at samfunnstjenesten har blitt bedre tilrettelagt for de dømte. Det synes som man særlig har strammet inn på bruk av reaksjonen overfor personer med store rusproblemer. Nedgangen i brudd har dessuten sammenfalt med reduksjonen i bruk av samfunnstjeneste, slik at det kan synes som man nå har skrellet vekk den tyngste gruppen.

I mars 1991 fikk vi en ny lov som regulere bruken av samfunnstjeneste. Nytt i denne loven er at man nå åpner opp for muligheten til å benytte samfunnstjeneste som en straffeskjerpelse i saker hvor betinget dom ellers ville vært alternativet. I perioden 1984 til 1991 ble det understreket i retningslinjene at samfunnstjenesten i størst mulig grad skulle fungere som et rent alternativ til ubetinget fengsel (Larsson 1991 og Røstad 1993). Man understreket at sanksjonen skulle benyttes overfor lovbrudd som ellers ville blitt gitt ubetinget fengsel i inntil 9 mnd, unntaksvis ett år. Tidligere ble det maksimale antall timer som kunne idømmes satt til 240, mens det etter lovfestingen åpner opp for å gi helt opp til 360 timer. Ved eksempelvis 240 timer idømmes man en gjennomføringstid på ett år, ved 120 timer seks måneder.

Kriteriene for hvem som kan idømmes samfunnstjeneste er klare. Den straffedømte bør ikke være for sosialt eller kriminelt belastet, ikke for ung (på grunn 
av motivasjonen), han bør ikke ligge under for "omfattende narkotika- eller alkoholmisbruk." Det stilles visse krav til psykisk helse, han skal ikke lide av "psykiatriske avvik" som det heter (Rundskriv G - 49/89, s. 5). Det oppfattes som en fordel at den dømte lever under relativt ordnede former, at han har arbeide og bosted. Reaksjonen retter seg i stor grad mot vinningskriminalitet, men åpner opp for flere andre former for lovbrudd, som mindre alvorlig narkotikakriminalitet. I 1995 var $72 \%$ av de dømte dømt for vinning, 9\% for vold og $15 \%$ for narkotikakriminalitet (St. meld. 271997 - 98). I praksis har disse retningslinjene ofte vært strukket en del. Hvis ikke ville man knapt funnet noen egnet til denne reaksjonen.

Samfunnstjenesten skal avtjenes i den dømtes fritid, det er ikke en frihetsstraff, men en fritidsstraff. Relativt ofte viser det seg at den dømte er arbeidsledig, arbeidet utføres derfor i vanlig arbeidstid. Den dømte soner vanligvis to ganger i uka på kveldstid eller en gang i løpet av helgen. Vanligvis tilsvarer dette fem timer i uka. Den domfelte făr en viss frihet ved valg av arbeidssted, noe som henger sammen med at han bør være motivert til arbeidet. Men det settes grenser av hvilke oppdrag som finnes tilgjengelige. Før han begynner soningen settes det opp en kontrakt med oppdragsiveren som skal overholdes.

Arbeidet som utføres er vanligvis praktisk forefallende oppdrag. Mange maler, pusser opp og snekrer for eksempel i idrettsklubber eller barnehager. Noen har oppgaver som ligner på vanlig vaktmesterarbeid. Kontorarbeid eller mer intellektuelle oppgaver er uvanlig. Oppdragsgiverne er vanligvis veldedige organisasjoner eller det offentlige. Det har ikke vist seg vanskelig å skaffe oppdragsgivere, det finnes mange arbeidsoppgaver som skulle vært gjort som det ikke finnes penger til å utføre. Dette har medført at mange av de som dømmes til samfunnstjeneste oppfatter arbeidet som meningsfullt. De ser nytten av det de gjør (Larsson 1994b).

Hvordan virker samfunnstjenesten? Ofte spørres det etter effektmålinger, noe vi knapt har (Hansen 1997 og Larsson 1999a). Vi kan derfor ikke besvare dette spørsmålet på noen god måte. I det hele tatt har det vært utført lite forskning på samfunnstjeneste og andre samfunnsstraffer i Norge de siste år. Det er derfor en rekke spørsmål som ikke kan besvares på noen grundig måte. Det gjelder for eksempel i hvilken grad samfunnstjenesten fungerer som et reelt alternativ til ubetinget fengsel. De fleste som arbeider med samfunnstjenesten mener at den i stor grad gjør det, men hvordan utviklingen har vært de siste årene vet vi lite om.

Tabell 1. Samfunnstjeneste dommer

\begin{tabular}{|l|c|c|c|c|c|c|c|c|}
\hline År & 1984 & 1989 & 1991 & 1994 & 1996 & 1998 & 1999 & 2000 \\
\hline $\begin{array}{l}\text { Antall } \\
\text { dommer }\end{array}$ & 24 & 268 & 760 & 1026 & 900 & 759 & 546 & 557 \\
\hline
\end{tabular}

(kilder Larsson 1999b og Justis dept ${ }^{2}$ ) 
Et av de mest markante trekk ved bruken av samfunnstjeneste de siste årene er den tydelige reduksjonen i antall dommer. Etter reaksjonen ble innført i 1984 $\emptyset \mathrm{kte}$ bruken jevnt og trutt i en tiårs periode frem til toppen ble nådd i 1994 med over 1000 dommer. Etter den tid har det vært en klar tilbakegang hvor bruken har blitt redusert med bortimot 50\%. Årsakene til nedgangen har vært debattert i media, de fleste opplevde reduksjonen som negativ. For at en skal kunne forklare bakgrunnen til utviklingen må det understrekes at det stort sett er tre mulige veier som kan føre frem til at samfunnstjeneste idømmes. Det mest vanlige er at politiet velger ut de saker de mener er passende. Disse sendes så til Kriminalomsorg i frihet som utfører en personunders $\varnothing$ kelse/egnethetsvurdering av den tiltalte. Stort sett følger dommerne disse vurderingene hvis saken faller inn under reaksjonens målfelt. Men forsvareren eller den tiltalte selv kan også foreslå samfunnstjeneste. Det er langt færre saker som kommer denne veien. En siste mulighet er at dommeren på eget initiativ ilegger samfunnstjeneste uten at verken aktor eller forsvarer har hevdet dette. Det er få som dømmes til samfunnstjeneste via denne veien.

Hva kan så forklare den markante nedgangen ${ }^{3}$ ? Mye tyder på at det har vært en reduksjon i saker fra hovedleverandøren, det vil si politiet. Flere steder påpeker dommere at de knapt mottar personunders $\varnothing$ kelser lenger eller at politiets rutiner synes å ha endret seg i retning av at sanksjonen har "gått i glemmeboka". De fleste uttrykker dette som et savn. Politiet på sin side har ofte opplevd disse bemerkninger som kritikk. De har, helt riktig, hevdet at dette like mye er forsvarsadvokatenes eget ansvar og at dommerne også bør være med å trekke i lag.

Det er liten grunn til å fremstille denne utviklingen på en konspiratorisk måte, at det skulle være politiets motforestillinger mot samfunnstjenesten som har gjort at bruken har blitt redusert. Å hevde at deler av politiet har oppfattet samfunnstjeneste som for mild straffereaksjon er ingen overdrivelse. Reaksjonen har i perioder blitt møtt med mye negativ presseomtale. Den har blitt karakterisert som en reaksjon som ikke er "straffende eller kontrollerende nok" (Hansen 1997, Larsson 1999a). Dette ble særlig intensivert i perioden etter 1994. Det er likevel neppe hovedårsaken til reduksjonen. Grunnen synes heller å ligge i de daglige rutiner for politijuristenes arbeide. Frem til lovfestingen i 1991 og en stund etter var det et klart påtrykk fra de sentrale myndigheter om at man ønsket mest mulig bruk av samfunnstjeneste. Dette ble stadig understreket ved skriv fra Riksadvokaten og ved direkte henvendelser. Dette var perioden for oppbygning og ekspansjon. Siden den tid har man i større grad latt reaksjonen seile sin egen sjø. Med stor rotasjon av politijurister og en stresset arbeidssituasjon så vil dette lett kunne medføre at man ikke lenger har samfunnstjenesten så present. Ved valg av hvilke reaksjoner man $\varnothing$ nsker blir det derfor lett at man velger andre alternativer, som fengsel. Dette er ikke merkverdig, mange dommere opplever samfunnstjenesten som en noe fremmed reaksjon, som et alternativ som kun passer i spesielle saker hvor individuelle trekk hos lovbryteren og hans livssitu- 
asjon er avgjørende. Det er ikke utenkelig at også politijurister deler dette synet på sanksjonen.

\section{Konfliktråd}

I 1976 utga Nils Christie artikkelen "Konflikt som eiendom". Det bærende perspektivet i denne artikkelen er at straffbare forhold er konflikter, og at disse bør løses på en sivil måte, i et direkte møte mellom partene som er involvert. Konflikter representerer et potensiale for folk og lokalsamfunn, hevder Christie. Ved at partene får løse sine egne konflikter åpnes det opp for deltakelse, for aktivitet og for innlevelse i hverandres situasjon. Dette kan i sin tur reaktivisere lokalsamfunn, motvirke fremmedgjøring og skape større nærhet mellom folk. I artikkelen skisseres også en modell for en legmannsbasert domstol. Denne skal være en erstatning for den strafferettslige kontrollen av lovbrudd, og den skal bygge på andre verdier enn strafferettens. Forsoning og gjenoppretting av relasjoner skal være grunnverdiene, ikke påføring av straff.

Artikkelen var en viktig forløper for opprettelsen av konfliktråd i Norge. I 1981 ble det første konfliktrådet opprettet, i Lier - en kommune noen få mil utenfor Oslo. Konfliktrådet ble opprettet som ledd i et fors $\varnothing \mathrm{k}$ på å finne alternativer til å straffe ungdommer. Fant man slike alternativer, var det politisk vilje til å heve den kriminelle lavalder fra 14 til 15 år. Av slike grunner ble konfliktrådet i Lier knyttet tett opp mot ungdomskriminalitet.

I dag - 20 år senere - er konfliktråd blitt en obligatorisk ordning for alle landets kommuner. Regler for virksomheten er nedfelt i "Lov om megling i konfliktråd" (av 15. mars 1991, nr. 3), og konfliktrådsbehandling er blitt en egen strafferettslig reaksjon. Aktiviteten i konfliktrådene har $\emptyset \mathrm{kt}$ kraftig etter som ordningen er bygget ut.

Hvilken type tiltak er så konfliktrådene blitt? Fungerer rådene som bredt anlagte konfliktløsningsorganer i lokalsamfunnene, eller ble rådene noe annet? Hvem er det som møtes i konfliktrådene, av hvilke grunner og med hvilken type konflikter? Er ordningen blitt et alternativ til straff? I det følgende skal vi behandle disse spørsmålene nærmere.

Målsettingene for konfliktrådsordningen er formulert slik i lovens forarbeider:

“- Å styrke lokalsamfunnets mulighet til å ta seg av lettere lovbrudd ved egen hjelp, og gi konfliktene tilbake til folket uten at dette medfører svekking av rettssikkerheten.

- A behandle bagatellmessige saker enkelt og hurtig, og med en reaksjon som er rask og konkret i forhold til handlingen som er blitt begått, derunder å øke muligheten for skadelidte for et raskt erstatningsoppgjør.

- Å la partene i en konflikt gjøre opp seg imellom ved hjelp av en megler, dette kan medvirke til å forebygge gjentakelser og gjensidige fordommer.

- Å la offeret få delta aktivt i å løse saken.

- Å gi lovbryteren et alternativ til andre aktuelle reaksjonsformer, en reaksjonsform som ikke medfører en plett på rullebladet." (Ot. prp. nr. 56 (1989-90), s. 9) 
Ifølge loven er det også slik at konfliktrådene skal være til for alle, og mange former for konflikter mellom folk skal kunne behandles i konfliktrådene, både sivile saker og straffesaker. Ordningen bygger på frivillighet. Parter kan komme av seg selv til konfliktrådet, både privatpersoner og offentlige instanser kan komme på lik linje med at påtalemyndigheten kan sende over straffesaker.

Det skal som nevnt være konfliktråd i alle kommuner; kommuner kan imidlertid slå seg sammen og opprette konfliktråd i fellesskap - såkalt interkommunale konfliktråd. Det enkelte konfliktråd ledes av en konfliktrådsleder. Perspektivet om konfliktrådenes tilknytning til lokalsamfunnene er framhevet i loven, og det er søkt ivaretatt ved at det skal være megler(e) i hver kommune, og ved at meglingen skal foregå i den påklagedes lokalsamfunn. Lovgiver har også understreket at det er partene som er involvert i den aktuelle konflikten som skal møtes. Derfor er partene pålagt å møte personlig; dog med mulighet for å ha med seg en bisitter. Det er også lovfestet at konfliktrådsordningen skal være legmannsorientert, meglerne skal være representanter for lokalsamfunnet, og de skal være "vanlige folk", det er ikke stilt noen krav til kvalifikasjoner el.l. Til nå har det vært et krav om at meglerne må ha fylt 25 år, men denne grensen er nå foreslått senket til 18 år (Ot. prp. nr. 79 (1999-2000)).

Det er partene selv som skal søke å komme fram til en Iøsning, men megleren kan bidra ved å foreslå løsninger og gi forslag til en avtale. En avtale som inngås kan enten gå ut på at det ytes erstatning til den skadelidte i form av penger eller arbeid, eller at partene snakker ut om forholdet. Det siste kalles ofte for "forhandlingsresultat". Meglerne avgjør om den avtalen partene har kommet fram til, skal godkjennes. Dersom avtalen i urimelig grad favoriserer den ene av partene, skal megleren nekte å godkjenne den.

Så langt loven. Vi ser at det er innslag av tanken om at konfliktrådene skal være alternative konfliktløsningsfora. Partene skal få gjøre opp i en konflikt seg imellom, konfliktrådene skal bidra til å gi offeret en mer sentral plass, og konfliktrådene skal være et alternativ til straff.

Men det ligger også andre føringer i ordningen. Justisdepartementet har innført målsettinger om at konfliktrådene skal ivareta en rask og enkel behandling av bagatellmessige saker. I tillegg er tanken om konfliktrådsbehandling som en form for "fornuftig" reaksjon for barn og ungdommer innført. Disse målsettingene er understreket av Justisdepartementet i flere sammenhenger; bl.a. i en kriminalpolitisk handlingsplan fra 1990. Der heter det: "De større straffesakene må avgjøres med domstolsbehandling. Konfliktråd som alternativ til straff i tradisjonell forstand kan bare være aktuelt i mindre saker (...) Reaksjonen knyttes konkret til den enkelte handlingen som er begått og er mer følbar enn det som ofte ville være alternativet ved en tradisjonell behandling (...)." Justisdepartementet har de senere år også uttalt at det er et mål å få flere barn under den kriminelle lavalder (15 år) til konfliktrådene. I St. prp. nr. 1 for 1994-95 heter det f.eks.: "Konfliktrådene må fortsatt tilstrebe bruk av ordningen overfor barn 
under 15 år." Justisdepartementet har også uttalt at innføringen av konfliktrådsordningen representerer ".. en differensiering av strafferettspleien, hvor muligheten til å finne en riktig reaksjon i det enkelte tilfelle nå er betydelig bedre." (St. melding 23 (1991-92), s. 90).

Vi ser altså at ordningen reserveres for de mindre alvorlige straffesakene, og man ønsker å bruke ordningen for barn under den kriminelle lavalder. Ordningen ses også som ledd i en differensiert strafferettspleie. Med dette knyttes ordningen tett opp mot det tradisjonelle strafferettsapparatet; konfliktrådsordningen blir nederste del av "reaksjonspyramiden". Dette er også i tråd med Riksadvokatens retningslinjer for ordningen.

For straffesakenes vedkommende, er det Riksadvokaten som gjennom Påtaleinstruksens kapittel 18A er gitt anledning til å gi nærmere bestemmelser om saksbehandlingen og hvilke saker som kan besluttes overført til konfliktrådet. Slike bestemmelser har Riksadvokaten gitt i et rundskriv fra 1993. Om hvilke strafferettslige reaksjoner konfliktrådsbehandling kan være et alternativ til, heter det: "Overføring til konfliktråd skal i første rekke skje i saker hvor reaksjonen ellers ville ha vært påtaleunnlatelse, bot eller betinget dom. Hvis saken kvalifiserer til ubetinget fengsel, kan den ikke avgjøres med konfliktrådsbehandling" (Rundskrivet, s. 2).

Ifølge straffeprosesslovens § $71 \mathrm{a}$, er et sentralt vilkår for overføring av en sak til megling i konfliktråd at påtalemyndigheten finner at saken "egner seg". Og riksadvokaten har gitt følgende regler for hvilke saker som er egnet og hvilke som ikke er egnet for konfliktrådsbehandling: Typiske saker er "... vinningskriminalitet, brukstyveri og skadeverk. Ordningen vil også kunne være egnet ved enkelte legemsfornærmelser, i første rekke når handlingen springer ut av en forutgående konflikt. Legemsbeskadigelser og saker med uprovosert vold er av almenpreventive grunner ikke egnet for behandling i konfliktråd: Disse skal normalt medføre ubetinget fengsel." (op. cit.)

Riksadvokaten avgrenser således ordningen mot å være et alternativ til frihetsstraff. ${ }^{4}$ Det følger også av dette at det kun er de mindre alvorlige former for lovbrudd som kan megles i konfliktrådene; handlinger som er definert til å være alvorligere - og som kan rammes av ubetinget fengselsstraff - kan ikke overføres til megling i konfliktråd.

I rundskrivet settes ikke noen $\emptyset$ vre aldersgrense for hvem som skal kunne møte i konfliktrådet. Men selv om det ikke settes noen $\emptyset$ vre aldersgrense, mener Riksadvokaten at konfliktrådsbehandling egner seg best for lovbrytere under 25 år, i og med at den "grensesettende virkningen" vil være størst for denne aldersgruppen. Han mener også at ordningen er “... særlig velegnet overfor unge og ubefestede lovovertredere." Dette fordi ordningen, samtidig som den representerer en "følbar reaksjon mot overtrederen", ikke har den samme "stigmatiserende virkning som tradisjonell straff". (op. cit.)

Konfliktrådsloven ble vedtatt i 1991, og den trådte i kraft for alle landets 
kommuner 1. april 1994. Loven har således fătt tid til å virke i noen år. Spørsmål som da reiser seg er hvordan ordningen har utviklet seg. Vi skal i det følgende se på noen hovedtall for virksomheten:

Bruken av ordningen har $\varnothing \mathrm{kt}$ etter lovens ikrafttredelse. I 1994 mottok konfliktrådene 3272 saker; i 1999 over dobbelt så mange: 6644 saker. Størst har $\emptyset$ kningen vært i det som betegnes som sivile saker. ${ }^{5}$ Mens $40 \%$ av sakene som ble mottatt i konfliktrådene i 1994 var sivile, var den tilsvarende andelen i 1999 $55 \%$. I og med at flertallet av de sivile sakene dreier seg om anmeldte lovbrudd med gjerningspersoner under den kriminelle lavalder, betyr økningen i sakstall de senere årene at konfliktrådene i økende grad er blitt et tiltak som fungerer som et supplement til det ordinære straffeapparatet. I så måte er Stan Cohens beskrivelse av det han mener er nøkkeltendenser i nyere kontrollmønstre i den vestlige verden treffende som beskrivelse av konfliktrådene: De nye samfunnsbaserte alternativer supplerer de opprinnelige kontrollmekanismer istedetfor å erstatte dem. Nye grupper fanges inn; grupper som uten tiltakets eksistens, ikke ville blitt møtt med noen reaksjoner (Cohen 1985).

Ikke alle saker som mottas i konfliktrådene går til megling; i alt ble det meglet 5240 saker i 1999. Av de meglede sakene er det de strafferettslige konfliktene som dominerer; $90 \%$ av sakene som ble meglet i 1999, dreide seg om et lovbrudd. Naskerier/tyverier er den sakskategorien som dominerer; $42 \%$ av de meglede sakene var naskeri- eller tyverisaker. Den nest største sakskategorien er skadeverk, som utgjorde $23 \%$ av de meglede sakene. Slår vi sammen disse sakskategoriene, ser vi at nesten to tredeler av sakene som ble meglet dreide seg om noen helt få lovbruddskategorier. Det er også sjelden det megles "rene" sivile saker i konfliktrådene.

Det er politiet som er leverer flest saker til konfliktrådene. Og det er stort sett saker der ungdommer er involvert som politiet oversender eller anbefaler for konfliktråd: To tredeler (67\%) av de som møtte som påklaget i 1999 var ungdommer under 18 år, 33\% var under 15 år. Flertallet er unge gutter. I meglingsmøtene møtte ungdommene ofte en representant for et firma; $51 \%$ av klagerne var en representant for et firma, en butikk eller en offentlig virksomhet. $45 \%$ av klagerne var privatpersoner.

Det ble inngått avtale i $91 \%$ av sakene som ble meglet i 1999. Erstatningsavtaler utgjorde $42 \%, 22 \%$ var arbeidsavtaler, $7 \%$ en kombinasjon av disse. $20 \%$ endte i forhandlingsresultat ( $9 \%$ endte med "annen avtale"). $80 \%$ av avtalene ble innfridd, $5 \%$ ble brutt, mens $15 \%$ er $1 \emptyset$ pende. ${ }^{6}$

Konfliktrådene er således i stor grad blitt fora for mindre alvorlig ungdomskriminalitet. Rådene kan vanskelig karakteriseres som bredt anlagte konfliktløsningsfora i lokalsamfunnene. I flere tilfeller er ordningen heller ikke noe alternativ til straff. Kanskje kan vi med Kjersti Ericsson konkludere på denne måten om hva konfliktrådene har blitt: "Det kan se ut som om både problemet som skulle løses og innholdet i løsninga endret seg i løpet av konfliktrådenes 
vandring fra ideenes verden til det praktiske liv. Løsninga endret seg fra et alternativ til det tradisjonelle strafferettsapparatet, basert på en ny ideologi om lovbrudd som konflikt mellom to parter, til et middel til å tvinge unge lømler som ellers ville sluppet for lett, til å "gjøre opp for seg". (...) Problemet endret seg fra fors $\emptyset \mathrm{k}$ på å finne alternativer til fengsel for unge lovbrytere, til søken etter hvordan man kunne få gitt ungdommer som aldri ville havnet i fengsel, en smekk over fingrene. Konfliktrådet ble samfunnets moralske pekefinger til de unge." (1996, s. 64-65).

Men selv om dagens konfliktråd ikke fungerer i tråd med de opprinnelige intensjonene, betyr ikke det at ideen om et sivilt konfliktløsningsorgan har slått feil. Dersom det er politisk vilje til det, kan selvfølgelig ordningen utvides til å omfatte mer alvorlige lovbrudd, og det er mulig å gjøre ordningen om til å bli et reelt alternativ til straff.

\section{Fra samfunnstjeneste til samfunnsstraff - noen utviklingstrekk innen bru- ken av samfunnssanksjoner.}

Det er noen hovedtrekk ved utviklingen av samfunnssanksjoner de siste 10 år som skal behandles avslutningsvis. Disse trekkene er:

- $\varnothing \mathrm{kt}$ utbredelse av ulike individualpreventive programmer

- søkelyset satt på kontroll, straff og styring av atferd

- Kriminalomsorg i frihet blir rene kontrollører og integrert i straffeapparatet

På en side kan disse utviklingstrekk virke paradoksale, de understreker både de straffende elementer og individuelle rehabiliterende momenter som læring. Det viser seg ved nærmere ettersyn at det ikke er noen direkte motsetninger mellom disse aspektene ved sanksjonene. Samfunnssanksjonene har under 1990-tallet stadig vært under politisk press i retning av at man skal stille strengere vilkår overfor de dømte, at kontrollen må bli mer omfattende og at dette ikke skal være alternativer for "alvorlig kriminelle". Den politiske høyresiden har stadig understreket behovet for at man idømmer flere timer samfunnstjeneste og at man har en tettere oppfølging av de dømte. Konfliktrådene benyttes ikke som alternativ i alvorlige saker, men tar seg stort sett av småsaker hvor ungdommer er involvert.

Ved det nye lovforslaget som ble lagt frem i Ot. prp. nr 52000 - 2001 så ble det foreslăt en ytterligere skjerping av tilsyn og kontroll av de dømte. Domstolene skal ikke lenger dømme til samfunnstjeneste, men til samfunnsstraff. Så er det opp til kriminalomsorgen å bestemme inneholdet i sanksjonen. Det er meningen at man skal benytte ulike tilsynsprogrammer sammen med samfunnstjeneste og ellers tilrettelegge soningen etter den enkelte dømte. Antallet timer man kan idømmes samfunnstjeneste er $\emptyset$ ket fra 360 til 420 timer. Det uttrykkes gang på gang at "straffen synes lite intensiv" og at det er "hensiktsmessig å forsterke straffeelementet noe". Samtidig synes det klart at den nye samfunnsstraffen (strl. § 28) vil havne mellom betinget og ubetinget fengsel på straffeskalaen 
og at man derved vil få mindre kontroll med hvorvidt samfunnstjeneste vil bli et rent alternativ til fengsel. Ved at denne loven gikk igjennom i Stortinget ${ }^{7}$ den 4 april 2001 har vi fulgt etter den internasjonale trenden og fått en mellomliggende straffereaksjon (intermediate sanction).

1990 årene har vært preget av en frisk vind av nye pedagogiske behandlingsopplegg innen det norske straffeapparatet. Foruten promilleprogrammer har vi i dag læringsopplegg i fengsel utviklet ut fra kognitiv psykologi og Canadiske forbilder. "Ny start" som det kalles er et frivillig opplegg for dømte (Danielsen og Hansen 1997). Siden 1995 har man hatt såkalte samtalegrupper for volds- og sedelighetsdømte. Dette er ikke en reaksjon man idømmes, den er frivillig for den enkelte innsatte (Isdal 1998). Samtalegruppenes målsetning er at å skape en situasjon hvor de dømte sitter og snakker sammen om vold. Man håper er at dette skal skape større bevissthet om egne voldshandlinger hos de dømte.

Kriminalomsorgen på sin side har arbeidet ut fra de pedagogiske perspektivene i konsekvenspedagogikken og realitetsterapien i sitt arbeide i hybelhusene og med samfunnstjenestedømte (Larsson 1993).

Tidligere ble det stadig understreket at KIF levde i spenning mellom hjelpeog kontroll oppgaver (St. meld. 1041977 - 78). Mange opplevde nok kontrolloppgavene som mest problematiske. I dag har de fleste av kriminalomsorgens hjelpeoppgaver blitt overlatt til andre instanser. Dette omtales som importmodellen $^{8}$. I løpet av 1990-tallet har KIF blitt stadig tettere integrert i det ordinære straffeapparatet (NOU 1993: 32 og St. meld. nr. 271997 - 98). Deres oppgaver har utviklet seg fra å være filantropiske hjelpeoppgaver i retning av å bli kontrollører og voktere.

Denne dreiningen i oppfatningen av samfunnsstraffer bygger på at kriminalpolitikken de senere år har blitt en viktig symbolpolitisk kampplass. Handlekraft innen kriminalpolitikken vises i dag ved å signalisere at man "tar problemene på alvor." Samtidig har ulike pedagogiske programmer seilt opp som noe man tror på, og "som virker". Det er atter noe galt ved lovbryteren som individ og person. Han er ikke lenger syk, men i stedet i behov av å lære å mestre sine tanker og følelser i ulike situasjoner. Han tenker negativt eller makter ikke å se konsekvensene av egne handlingsvalg. Pendelen har nok engang svingt tilbake til særbehandlingsopplegg, samtidig som de punitive sidene ved straffen understrekes.

REFERANSER:

Andenæs, Johs: "Alminnelig strafferett" 4. utgave, Universitetsforlaget Oslo, 1997.

Andersson, Jan: "Elekronisk övervakning som alternativ till fängelse" i Rapport fra NSFKs 18. kontaktseminar og 39. forskerseminar Hirtshalls, Danmark, 1997.

Christie, Nils: "Konflikt som eiendom." I: Som folk flest. Universitetsforlaget, Oslo, 1978.

Cohen, Stanley: "Visions of Social Control", Polity Press, Cambridge, 1985.

Danielsen, Trond og Wilhelm Meek Hansen: "Ny start for norsk fengselsvesen”, Krus, Kriminalomosrgense utdanningssenter, Oslo, 1997. 
Ericsson, Kjersti: "Forsømte eller forbryterske". Ad Notam Gyldendal AS, Oslo, 1996.

Eskeland, Ståle: "Fangerett. En studie av rettssikkerhet ved fullbyrdelse av fengselsstraff.", Tano, Oslo, 1989.

Hansen, Rune B: "Forhindrer samfunnstjeneste kriminalitet? Erfaringer fra et politidistrikt" i Lov og Rett, 1997.

Holmboe, Morten: "Konfliktrådloven. Lov om megling i konfliktråd av 15. mars 1991 nr. 3". Universitetsforlaget, Oslo, 1996.

Innst. S. Nr. 6. 1998 -99. Innstilling fra justiskomiteen om kriminalomsorgen ...

Isdal, Per: "Håndbok for samtalegrupper for volds- og sedelighetsdømte", KRUS Håndbok, Oslo, 1998.

Konfliktrådsstatistikk 1999, Justisdepartementet

Kriminalomsorgens Årbok 1999, Justis- og politidepartementet

Kristoffersen, Ragnar: "Promilleprogram i friomsorgen", KRUS, Oslo, 1999.

Larsson, Paul: "Et konstruktivt onde?", Magistergradsavhandling i kriminologi, Oslo, 1991. - "Pedagogikkens inntog", i Nordisk tidsskrift for kriminalvidenskab, nr. 1, 1993.

- "Ved alvorlig eller gjentatt brudd ..." K - serien nr. 1, Institutt for kriminologi, Oslo, 1994.

- "Samfunnsstraffer og påvirkningsprogrammer - Nye utfordringer?", i Aktiv kriminalomsorg - et tryggere samfunn, Rapport fra kriminalpolitisk konferanse, Norges Fengselstjenestemannsforbund, Fellesorganisasjonen, 1998.

- "Residiv ved samfunnstjeneste" i Lov og Rett, nr. 6, 1999a.

- "Community service, Lots ..." i Overcrowded times, nr. 1, 1999b.

NOU 1993: 32 "Nytt fundament for friomsorgen"

Ot. prp. nr. 5 (2000 - 2001) Om lov om gjennomføring av straff mv. (straffegjennomføringsloven)

Ot. prp. nr. 56 (1989-90) Om lov om megling i konfliktråd og om endringer i straffeloven m.m. Justis- og politidepartementet.

Petersilia, Joan: "Community Corrections. Probation, Parole, and Intermediate Sanctions", Oxford University Press, 1998.

Riksadvokatens rundskriv, 1993

Røstad, Helge: "Innkast i straffefeltet. Utvalgte emner i strafferett", Univetsitetsforlaget, Oslo,1993.

Stortingsmelding nr. 1041977 - 78. "Om kriminalpolitikken"

Stortingsmelding nr. 271997 - 98. "Om kriminalomsorgen".

St. prp. nr. 1, 2000-2001, Justis- og politidepartementet

Tonry, Michael og Kate Hamilton (eds): "Intermediate Sanctions in Overcrowded Times.", NUP, Chicago, 1995.

\section{NOTER:}

'Etter fengselslovens $§ 12$ kan den dømte overføres til soning ved "sikringsanstalt, pleieanstalt, kursted eller annen behandlingsinstitusjon for en gjenstående del av straffetiden." Slik overføring kan finne sted når det finnes hensiktsmessig på grunn av helbred, sinnstilstand og andre grunner (se Eskeland 1989).

${ }^{2}$ Takk til Jan Erik Sandlie og Hans Gunnar Stey ved Kriminalomsorgsavdelingen i Justis departementet som alltid er en like behjelpelig med informasjon.

${ }^{3}$ Disse slutninger bygger på Larssons undersøkelse av dommeres bruk av samfunnsreaksjoner i perioden 1998 - 2000. Spørsmålet om nedgangen var ikke det mest sentrale i disse intervjuer, men kom likevel opp relativt ofte blant annet uttrykt som en viss frustrasjon over mangel på saker.

${ }^{4}$ Her må nevnes at det i rundskrivet åpnes for at konfliktrådsbehandling kan settes som særlig vilkår i en betinget dom. Hvis domstolene benytter seg av dette som et reelt vilkår (dvs. at konfliktrådsbehandling ikke kommer som et tilleggsvilkår i en dom som ville blitt betinget uansett), kan konfliktrådsbehandling fungere som et alternativ til frihetsstraff. Så vidt vi kjenner til, benytter imidlertid domstolene nesten aldri konfliktrådsbehandling som vilkår i betingede dommer. 
${ }^{5}$ Betegnelsen er noe misvisende, siden størsteparten av de sivile sakene dreier seg om anmeldte lovbrudd med gjerningspersoner under 15 år.

${ }^{5}$ Når meglingen i en straffesak er avsluttet, skal konfliktrådet sende sakens dokumenter tilbake til påtalemyndigheten med opplysning om det er inngått en godkjent avtale mellom partene. Når avtalen er oppfylt, skal konfliktrådet også sende en bekreftelse om dette til påtalemyndigheten. I tillegg skal konfliktrådet varsle påtalemyndigheten hvis den siktede bryter avtalen (lovens $\S 15$ ). Påtalemyndigheten kan bare åpne straffeforfølgning på ny dersom den siktede bryter avtalen vesentlig (§ 16). Forarbeidene sier ikke noe om hva som skal til for at et avtalebrudd er vesentlig nok til å åpne ny straffeforfølgning. Ifølge Holmboe (1996) må man i utgangspunktet skjele til forholdet mellom den inngåtte avtale og hva den siktede har bidratt med. Ellers er også årsaken til avtalebruddet viktig; om det skyldes personlige vanskeligheter hos den siktede eller "giddeløshet".

${ }^{7}$ Det opplyses at Ot. prp.nr. 5 (2000-2001) gikk igjennom i Stortinget uten at det skjedde større forandringer i forhold til forslagene i proposisjonen.

${ }^{8}$ I dag er importmodellen omdøpt til forvaltningssamarbeide, inneholdet er imidlertid det samme. Kriminalomsorgen kan yte noe økonomisk støtte, men ellers er kriminalomsorgens oppgave å hjelpe den dømte til å komme i kontakt med det ordinære sosiale hjelpe apparat. Hovedtanken er at dømte som er under kriminalomsorgens tilsyn skal ha muligheter til å motta hjelp og sosiale stønader på lik linje med andre. Ofte har imidlertid dømte mange preserende problemer som er av en annen art enn "normale" sosial klienters.

Adresse: Paul Larsson

Politidistrikt PB 8051 Rep. N-0031 Oslo
Jane Dullum

Intstitutt for Kriminologi PB 6706 St. Olavs plass N-0130 Oslo 